\title{
Cryopreservation protocol for equine platelet-rich plasma
}

\section{Protocolo de criopreservação para plasma rico em plaquetas de equinos}

\author{
Liomara Andressa do Amaral Kwirant ${ }^{1 *}$; Flavio Desessards De La Corte ${ }^{2}$; \\ Karin Erica Brass²; Mara Iolanda Batistella Rubin²; Raqueli Teresinha França ${ }^{3}$; \\ Patrícia Soares Vieira ${ }^{4}$; Mariana Cocco $^{5}$
}

\begin{abstract}
In this preliminary study, a new equine platelet-rich plasma (PRP) cryopreservation protocol was evaluated. PRP was obtained by a double centrifugation technique of whole blood collected from 8 adult healthy ponies. A fresh sample of PRP was analyzed for total platelet count, mean platelet volume (MPV), and platelet morphology. Upon morphological evaluation, 200 platelets were counted using a differential interference contrast microscope with a 40x phase objective and classified as activated (with pseudopodia), inactivated (normal discoid shape), or uncertain state (spherical shape, without pseudopodia). Two other PRP samples, one containing DMSO as a cryoprotectant and the other without DMSO, were stored in a mechanical freezer at $-80^{\circ} \mathrm{C}$. After 14 days, the frozen samples were thawed and submitted to the same analysis as described above. The fresh PRP showed a platelet count of 830 $( \pm 95.3) \times 10^{3} \mu \mathrm{L}^{-1}$, an MPV of $5.2( \pm 0.07) \mathrm{fL}$, and composed of $4 \%$ activated platelets. There was no significant difference in platelet count, MPV, and activated platelets between fresh and $6 \%$ DMSO frozen PRP samples $\left(617.9 \pm 65.5 \times 10^{3} \mu \mathrm{L}^{-1} ; 5.3 \pm 0.06 \mathrm{fL} ; 9.5 \%\right)(\mathrm{p}>0.05)$. On the other hand, samples frozen without DMSO showed a significantly lower platelet count $\left(519.6 \pm 66.1 \times 10^{3} \mu \mathrm{L}^{-1}\right)$, higher MPV $(5.7 \pm 0.08 \mathrm{fL})$, and more activated platelets $(13.9 \%)$ than the other groups $(\mathrm{p}<0.05)$. The $6 \%$ DMSO was able to preserve platelet morphology in PRP stored at $-80^{\circ} \mathrm{C}$ for 14 days, but studies on platelet function of thawed PRP are still needed.
\end{abstract}

Key words: Platelets. Storage. Equine. Dmso.

\section{Resumo}

Neste estudo preliminar, um novo protocolo de criopreservação de plasma rico em plaquetas (PRP) de equinos foi avaliado. O PRP foi obtido através de dupla centrifugação do sangue total coletado de oito pôneis clinicamente saudáveis. Uma amostra de PRP fresco foi analisada quanto ao número total de plaquetas, volume plaquetário médio (VPM) e morfologia plaquetária. Na avaliação morfológica 200 plaquetas foram contadas utilizando um microscópio com contraste de fase com objetiva de 40x e classificadas como ativadas (com pseudópodes), inativas (forma discóide normal) ou estado incerto (forma esférica, mas sem peseudópodes). Duas outras amostras de PRP foram armazenadas em um freezer mecânico a $-80^{\circ} \mathrm{C}$, uma contendo dimetil sulfóxido (DMSO) como crioprotetor e outra sem

\footnotetext{
${ }^{1}$ Discente no Programa de Pós-Graduação em Medicina Animal - Equinos, Universidade Federal do Rio Grande do Sul, UFRGS, Porto Alegre, RS, Brasil. E-mail: liomara_amaral@hotmail.com

2 Profs. Associado, Departamento de Clínica de Grandes Animais, Universidade Federal de Santa Maria, UFSM, Santa Maria, RS, Brasil.E-mail: delacorte2005@yahoo.com.br; kbrass@terra.com.br; mararubin90@yahoo.com.br

${ }^{3}$ Discente no Programa de Pós-Graduação em Medicina Veterinária, UFSM, Santa Maria, RS, Brasil. E-mail: raquelifranca@ gmail.com

${ }^{4}$ Discente no Programa de Pós-Graduação em Medicina Veterinária, Universidade Federal de Pelotas, UFPEL, Pelotas, RS, Brasil. E-mail: patricia10.vieira@hotmail.com

${ }^{5}$ Discente de Graduação em Medicina Veterinária, UFSM, Santa Maria, RS, Brasil. E-mail: mariana.cocco@hotmail.com

* Author for correspondence
} 
DMSO. Após 14 dias as amostras congeladas foram descongeladas e submetidas às mesmas avaliações das amostras frescas. O PRP fresco apresentou contagem plaquetária de $830( \pm 95,3) \times 10^{3} \mu \mathrm{L}^{-1}$, VPM $5,2( \pm 0,07) \mathrm{fL}$ e $4 \%$ de plaquetas ativadas. Não houve diferença na contagem plaquetária, VPM e plaquetas ativadas entre as amostras de PRP frescas e congeladas com $6 \%$ de DMSO $\left(617,9 \pm 65,5 \times 10^{3}\right.$ $\left.\mu \mathrm{L}^{-1} ; 5,3 \pm 0,06 \mathrm{fL} ; 9,5 \%\right)$ ( $\left.>0,05\right)$. Por outro lado, as amostras congeladas sem DMSO apresentaram uma contagem de plaquetas significativamente menor $\left(519,6 \pm 66,1 \times 10^{3} \mu \mathrm{L}^{-1}\right)$, maior VPM $(5,7 \pm 0,08 \mathrm{fL})$ e mais plaquetas ativadas $(13,9 \%)$ do que os outros grupos $(\mathrm{p}<0,05)$. DMSO a $6 \%$ foi capaz de preservar a morfologia plaquetária no PRP armazenado a $-80^{\circ} \mathrm{C}$ durante 14 dias, mas estudos a respeito da função plaquetária ainda não necessários.

Palavras-chave: Plaquetas. Armazenamento. Equino. Dmso.

\section{Introduction}

Platelets play an important role in hemostasis, wound healing, and re-epithelization, releasing several growth factors contained in $\alpha$-granules that stimulate angiogenesis and promote vascular growth and fibroblast proliferation (VENDRAMIN et al., 2006). Platelets are found in blood in an inactive state; when activated, platelets undergo a change in their morphology, emitting pseudopodia that promote platelet aggregation and subsequent release of granular contents (EVERTS et al., 2006).

Platelet rich-plasma (PRP) is an autogenous source of easily obtainable and inexpensive growth factors derived from whole blood. By definition it must contain three to five times more platelets than physiological levels (GONSHOR, 2002). In horses, PRP has been clinically used to repair different injuries such as bone lesions (CARMONA; LÓPEZ, 2011), joint lesions, (CARMONA et al., 2007; PICHEREAU et al., 2014) and soft tissue lesions (tendinitis, desmitis) (MAIA et al., 2009). Recently, Carmona et al. (2013) used PRP in the treatment of a horse with chronic laminitis secondary to Cushing's syndrome and observed faster growth and lower hoof lameness after two applications of PRP at the coronary band. PRP has also been applied to the treatment of mares susceptible to post-coverage endometritis, reducing the inflammatory response after artificial insemination and increasing fertility rates (METCALF, 2014; REGHINI et al., 2014). However, to the best of our knowledge there is no report on the number of PRP applications needed to achieve cure of various injuries.
Considering the need of repeated PRP treatments and its viability outside a hospital environment, PRP storage is a crucial aspect to be considered. However, the maximum recommended period for PRP use is only eight hours after preparation (MARX, 2004) because growth factors are secreted actively by $\alpha$-granules during the first 10 minutes after platelet activation, and over $95 \%$ of presynthesized growth factors are released in the first hour (KEVY; JACOBSON, 2001). Furthermore, when cooled at temperatures below $20^{\circ} \mathrm{C}$, platelets undergo severe damage, including changes from discoid to spherical shaped pseudopodia, sharp rise in intracellular calcium, and fusion and secretion of their dense, lysosomal and $\alpha$-granules, a process that mimics physiological activation (TABLIN et al., 2001). On the other hand, when stored at room temperature, platelets have a short shelf life. In blood banks, human platelets are stored at $22^{\circ} \mathrm{C}$ for a maximum time of only five days due to an increased risk of bacterial contamination (SCHOENFELD et al., 2006).

Over the years, several researchers have developed storage methods in order to increase the platelet shelf life. Freezing platelets with dimethyl sulfoxide (DMSO; $5 \%$ or $6 \%$ ) currently represents the standard for long-term platelet cryopreservation (LEE; BLAJCHMAN, 2007). Additionally, the American Association of Blood Banks approves the cryopreservation of human platelets with $6 \%$ DMSO as an acceptable method of storage (APPLEMAN et al., 2009). Platelets can be stored in $6 \%$ DMSO at $-80^{\circ} \mathrm{C}$ for up to two years without 
significant loss of their properties (MELARAGNO et al., 1985), whereas platelets frozen in 5\% DMSO at $-150^{\circ} \mathrm{C}$ can be stored for three years (DALY et al., 1979). Recently, Dumont et al. (2013) assessed the recovery and post-transfusion survival rates of cryopreserved platelet concentrates in 6\% DMSO kept at $-65^{\circ} \mathrm{C}$ in a freezer for 7 to 13 days. They observed measurable platelet recovery and survival in the blood circulation for approximately seven days after the transfusion, suggesting maintenance of hemostatic effects of the cryopreserved platelets. Cryopreserved platelet concentrates in DMSO have also been used in military operations, particularly in cases of massive blood loss and no availability of fresh platelet concentrates (NEUHAUS et al., 2010). Platelet cryopreservation results in expression of phosphatidylserine, which contributes to increased hemostatic activity, as described by Johnson et al. (2014). However, little is known about equine PRP cryopreservation. Therefore, this study was performed to evaluate the efficacy of DMSO as a cryoprotectant in equine PRP storage.

\section{Materials and Methods}

\section{PRP preparation}

To obtain PRP, eight clinically healthy ponies (seven males and one female) with a mean age of nine years and a mean weight of $200 \mathrm{~kg}$ were used. PRP was prepared according to the protocol developed by Pereira et al. (2013). Whole blood (500 ml) was aseptically drawn from the jugular vein in a blood collection bag containing anticoagulant made of citrate, phosphate, dextrose, and adenine (CPDA). A $2 \mathrm{ml}$ blood sample was sent for laboratory tests (complete blood and platelet count).

A volume of $100 \mathrm{ml}$ blood was split and placed into two $50 \mathrm{ml}$ polypropylene tubes. The remainder was discarded. The tubes were centrifuged at $224 \mathrm{~g}$ for 10 minutes. The plasma fraction (adjacent to the Buffy coat) was aspirated, placed in new tubes, and centrifuged a second time at $440 \mathrm{~g}$ for 10 minutes to obtain PRP. The supernatant platelet poor-plasma was discarded. From each $100 \mathrm{ml}$ of blood, $10 \mathrm{ml}$ of PRP were obtained and divided into three $2 \mathrm{ml}$ aliquots in Eppendorf tubes. One of these tubes (fresh PRP) was sent for laboratory tests, the second one (6\% DMSO PRP) was cryopreserved with $6 \% \mathrm{DMSO}$, and the third one (frozen PRP) was cryopreserved without DMSO. The remaining PRP was discarded.

\section{Laboratory tests}

Laboratory tests were performed blindly by a single clinical pathologist. The tests consisted of platelet count, determination of mean platelet volume (MPV), and platelet morphological evaluation. Platelet counting was performed in a Neubauer chamber (BRECHER et al., 1953) and the MPV was determined using an automated hematology analyzer (Mindray BC-2800Vet). Platelet morphology was assessed using a differential interference contrast microscope with a 40x phase objective (APPLEMAN et al., 2009). Two hundred platelets were counted and classified as: inactive (normal discoid shape), activated (spherical shape with pseudopodia), or uncertain state (spherical shape, without pseudopodia) (WÜRZINGER; SCHMID-SCHÖNBEIN, 1990).

\section{PRP Cryopreservation}

The cryopreservation protocol was performed according to Valeri et al. (1974). With a $1 \mathrm{ml}$ syringe, samples to be cryopreserved $(1.88 \mathrm{ml}$ PRP) received DMSO $(0.12 \mathrm{ml})$ slowly mixed $\left(1 \mathrm{mlminute}{ }^{-1}\right)$ to reach a $6 \%$ DMSO concentration (6\% DMSO PRP). Another PRP sample (2ml) was stored without DMSO (frozen PRP). Both aliquots were placed directly into a mechanical freezer at $-80^{\circ} \mathrm{C}$ and stored for 14 days.

After this period, all samples were thawed in a $37^{\circ} \mathrm{C}$ water bath for five minutes, and 15 minutes post thawing, they were subjected to the same laboratory tests described above. 


\section{Statistical analysis}

The results were analyzed using ANOVA, and multiple comparisons of means were performed by the Tukey test. All analysis was performed using GraphPad Prism 5.0 software with significance indicated as $\mathrm{p}<0.05$. Data are presented as mean \pm standard error.

\section{Results}

\section{Platelet count}

The mean number of platelets in whole blood was $167.8( \pm 23.3) \times 10^{3} \mu \mathrm{L}^{-1}$. In fresh PRP, the mean number of platelets $\left(830 \pm 95.3 \times 10^{3} \mu \mathrm{L}^{-1}\right)$ did not differ from the number observed in 6\% DMSO PRP $\left(617.9 \pm 65.5 \times 10^{3} \mu \mathrm{L}^{-1}\right)(\mathrm{p}>0.05)$, but it was above the mean of platelets in frozen PRP $(519.6 \pm 66.1$ $\left.\mathrm{x} 10^{3} \mu \mathrm{L}^{-1}\right)(\mathrm{p}<0.05)$. The platelet recovery rate after thawing was $74.5 \%$ and $62.6 \%$ in $6 \%$ DMSO PRP and frozen PRP samples, respectively.

\section{$M P V$}

The MPV observed in whole blood was $6.0( \pm$ $0.1) \mathrm{fL}$. Among the cryopreserved samples, frozen PRP showed the highest volume $(5.7 \pm 0.08 \mathrm{fL})$ $(p<0.05)$, with no difference between fresh PRP (5.2 $\pm 0.07 \mathrm{fL})$ and 6\% DMSO PRP $(5.3 \pm 0.06 \mathrm{fL})(\mathrm{p}>$ $0.05)$.

\section{Platelet concentration}

Fresh PRP showed a mean platelet concentration of $5.2( \pm 0.5)$ times the number present in whole blood. After thawing, 6\% DMSO PRP showed a platelet concentration of $4.0( \pm 0.5)$ times the original, while the frozen PRP showed a platelet concentration of $3.2( \pm 0.2)$ times.

\section{Morphological evaluation}

Figure 1 represents platelets in fresh and cryopreserved PRP. In the sample of fresh PRP (Figure 1A), 74\% of the platelets were classified as being in an inactive state, and only $4 \%$ of the platelets were activated. The $6 \%$ DMSO PRP sample (Figure 1B) also mostly showed platelets in an inactive form $(51 \%)$, although there was an increase in the number of platelets in the uncertain state compared to fresh PRP (39.5\% and 22\%, respectively). As for the number of activated platelets, there was no significant difference between the fresh PRP (4\%) and 6\% DMSO PRP (9.5\%) ( $\mathrm{p}>0.05)$. Moreover, the frozen PRP (Figure 1C) showed 14\% of activated platelets, $16 \%$ of inactive platelets, and mainly platelets in uncertain state $(70 \%)$.

\section{Discussion}

PRP contains many growth factors and has an important role in wound healing due to its mitogenic, chemotactic, and neovascular function. By definition, PRP derived from whole blood must contain at least three to five times more platelets than physiological levels (GONSHOR, 2002), which in horses range from 100,000 to $350,000 \mu \mathrm{L}^{-1}$ (GRONDIN; DEWITT, 2010). According to Anitua et al. (2004), a platelet count greater than 300,000 $\mu \mathrm{L}^{-1}$ is sufficient. In the present study, both fresh and frozen PRP samples produced by the protocol chosen contained at least three times more platelets than the whole blood.

The recovery rate of platelets in equine PRP after DMSO cryopreservation was similar to that observed in human platelet concentrates. According to Lee and Blajchman (2007), in vitro platelet recovery after freezing is 75\%. Appleman et al. (2009) working with canine platelets obtained an in vitro platelet recovery of $72.8 \%$, using $6 \%$ DMSO as cryoprotectant. The platelet recovery rate in PRP without DMSO was much lower, which means that DMSO was effective in protecting the equine PRP during freezing. 
Figure 1. Platelets in fresh PRP (A) and cryopreserved PRP (B and C). A: Fresh PRP sample, showing inactive platelets with normal, discoid shape (white arrows); B: 6\% DMSO PRP post thawing sample, showing mostly inactive platelets (white arrow), a few activated platelets (red arrow), and uncertain state platelets (empty white arrow); C: Frozen PRP sample (without DMSO) post thawing, showing mostly uncertain state platelets and some activated platelets with long pseudopods (red arrows) (Differential interference contrast microscope with a $40 x$ phase objective).
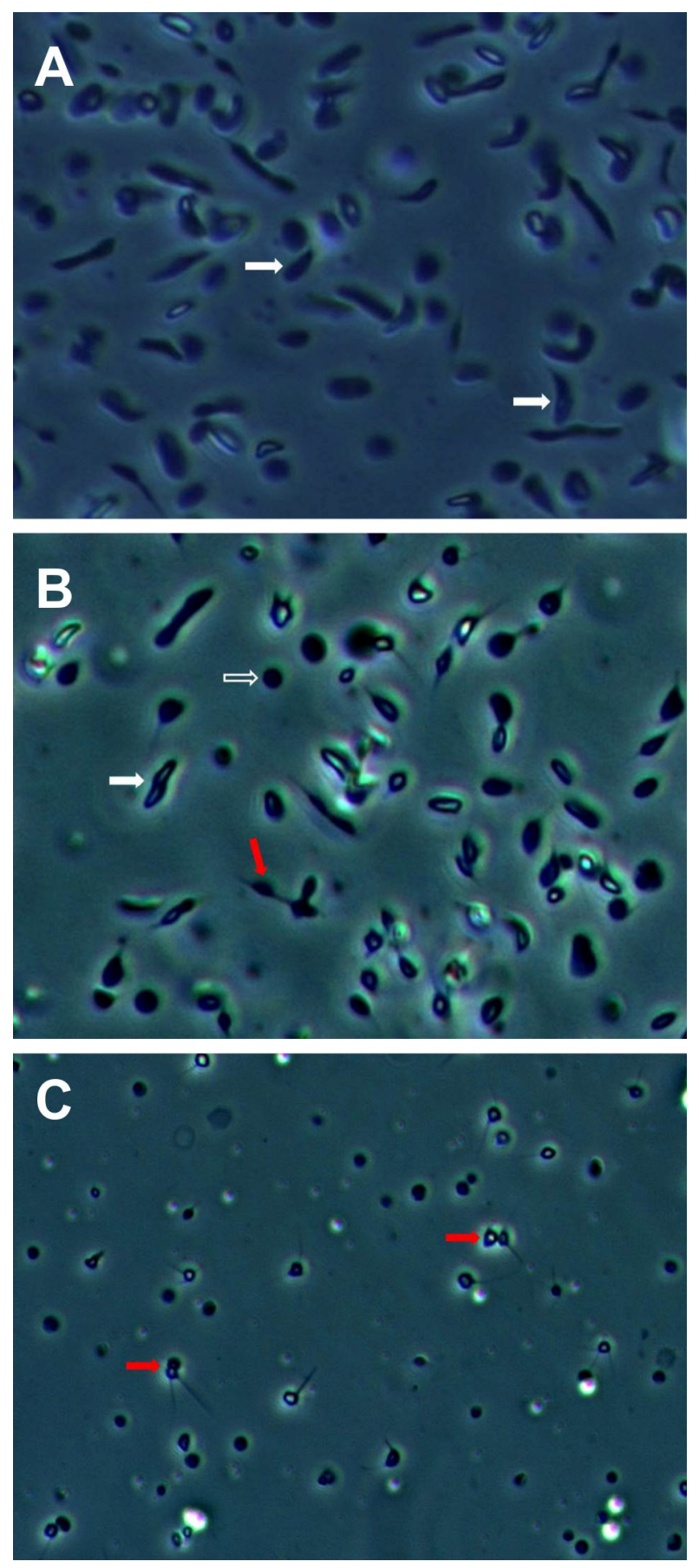

MPV ranges from 4.3 to $5.6 \mathrm{fL}$ in horses (GRONDIN; DEWITT, 2010). During the cryopreservation of human platelet concentrates with DMSO, an increase in MPV (BÖCK et al., 1995; LANDI et al., 2004) was observed. In this study, however, the MPV of $6 \%$ DMSO PRP samples was not different from the fresh PRP. Only the MPV of frozen PRP (without DMSO) increased significantly. An increase of MPV is indicative of platelet lesion. A first reduction in MPV occurs due to platelet fragmentation or microparticles formation, and the subsequent rise in MPV occurs due to swelling of the cells (OHTO; NOLLET, 2011). MPV in PRP was lower than that observed in whole blood, which may indicate that there was some degree of platelet fragmentation during the PRP preparation.

Platelet morphology is used as one assessment criteria of the activation state, and in the latter stages of storage, platelet membrane integrityis evaluated (DEVINE; SERRANO, 2010). Appleman et al. (2009) evaluated the morphology of dog platelets preserved with $6 \%$ DMSO and Thrombosol, under phase contrast microscopy, as a quality parameter, and no significant differences between fresh and cryopreserved platelet concentrates were observed. Zandim et al. (2012), using electron microscopy, evaluated morphological changes of equine platelets in PRP samples activated with different pharmacological agents and observed an increase in complete platelet activation rate when PRP was activated with calcium chloride.

In this study, the proportion of activated platelets found in DMSO PRP did not differ from that found in fresh PRP, suggesting that the cryopreservation process resulted in no significant increase in platelet activation. Moreover, although using phase contrast microscopy to evaluate platelet morphology, an increase in the number of activated platelets in frozen PRP was observed, suggesting that when stored without a cryoprotectant, platelets contained in the PRP in the absence of DMSO suffered early activation induced by low temperature. 
Fresh PRP had the highest count of inactive platelets, differing from the findings of Zandim et al. (2012), who found a greater number of platelets with uncertain form before activation. The platelet morphology classified as uncertain was present in larger numbers in frozen PRP. Zandim et al. (2012), after activating PRP with calcium chloride, noted that the most frequent platelet morphology was the uncertain state. However, platelets with uncertain shape also increased in 6\% DMSO PRP when compared to fresh PRP, indicating that platelets had undergone some degree of activation due to freezing.

\section{Conclusion}

In this study, 6\% DMSO was able to protect platelets contained in PRP from damage caused by storage at low temperatures. However, it is still necessary to evaluate whether platelets contained in PRP stored at $-80^{\circ} \mathrm{C}$ in the presence of DMSO are still able to release growth factors, since this is the point when PRP is used in the treatment of lesions in equine medicine.

\section{Acknowledgments}

The authors thank CAPES - Coordenação de Aperfeiçoamento de Pessoal de Nível Superior (Coordination for Improvement of Personnel in Higher Education) and $\mathrm{CNPq}$ - Conselho Nacional de Desenvolvimento Científico e Tecnológico (National Council for Scientific and Technological Development) for granting a master's studies scholarship to the first author.

\section{References}

ANITUA, E.; ANDIA, I.; ARDANZA, B.; NURDEN, P.; NURDEN, A. T. Autologous platelet as a source of proteins for healing and tissue regeneration. Thrombosis and Haemostasis, Stuttgart, v. 91, n. 1, p. 4-15, 2004.
APPLEMAN, E. H.; SACHAIS, B. S.; PATEL, R.; DROBATZ, K. J.; GROMAN, R. P.; KENNEDY, D. R.; O'DONNELL, P. A.; BRYAN, C.; CALLAN, M. B. Cryopreservation of canine platelets. Journal of Veterinary Internal Medicine, Philadelphia, v. 23, n. 1, p. 138-145, 2009.

BÖCK, M.; SCHLEUNING, M.; HEIM, M. U.; MEMPEL, W. Cryopreservation of human platelets with dimethyl sulfoxide: changes in biochemistry and cell function. Transfusion, Arlington, v. 35, n. 11, p. 921-924, 1995.

BRECHER, G.; SCHNEIDERMAN, M.; CRONKITE, E. P. The reproducibility and consistency of the platelet count. American Journal of Clinical Pathology, Philadelphia, v. 23, n. 1, p. 15-26, 1953.

CARMONA, J. U.; ARGUELLES, D.; CLIMENT, F.; PRADES, M. Autologous platelet concentrates as a treatment of horses with osteoarthritis: a preliminary pilot clinical study. Journal of Equine Veterinary Science, Wildomar, v. 27, n. 4, p. 167-170, 2007.

CARMONA, J. U.; LÓPEZ, C. Autologous platelet concentrates as a treatment for shoulder injury in a horse. Journal of Equine Veterinary Science, Wildomar, v. 31, n. 9, p. 506-510, 2011.

CARMONA, J. U.; LÓPEZ, C.; SAMUDIO, I. J. Autologous platelet concentrates as an adjunctive treatment for chronic laminitis in a mare with pituitary pars intermedia dysfunction. Journal of Equine Veterinary Science, Wildomar, v. 33, n. 3, p. 191-195, 2013.

DALY, P. A.; SCHIFFER, C. A.; AISNER, J.; WIERNIK, P. H. Successful transfusion of platelets cryopreserved for more than 3 years. Blood, New York, v. 54, n. 5, p. 1023-1027, 1979.

DEVINE, D. V.; SERRANO, K. The platelet storage lesion. Clinics in Laboratory Medicine, Philadelphia, v. 30, n. 2, p. 475-487, 2010.

DUMONT, L. J.; CANCELAS, J. A.; DUMONT, D. F.; SÍEGEL, A. H.; SZCZEPIORKOWSKI, Z. M.; RUGG, N.; PRATT, P. G.; WORSHAM, D. N.; HARTMAN, E. L.; DUNN, S. K.; O'LEARY, M.; RANSOM, J. H.; MICHAEL, R. A.; MACDONALD, V. W. A randomized controlled trial evaluating recovery and survival of $6 \%$ dimethyl sulfoxide-frozen autologous platelets in healthy volunteers. Transfusion, Arlington, v. 53, n. 1, p. 128$137,2013$. 
EVERTS, P. A. M.; KNAPE, J. T. A.; WEIBRICH, G.; SCHÖNBERGER, J. P. A. M.; HOFFMANN, J.; OVERDEVEST, E. P.; BOX, H. A. M.; VAN ZUNDERT, A. Platelet-rich plasma and platelet gel: a review. The Journal of Extra-Corporeal Technology, Saint Paul, v. 38, n. 2, p. 174-187, 2006.

GONSHOR, A. Technique for producing platelet-rich plasma and platelet concentrate: background and process. The International Journal of Periodontics \& Restorative Dentistry, Chicago, v. 22, n. 6, p. 547-557, 2002.

GRONDIN, T. M.; DEWITT, S. F. Normal hematology of the horse and donkey. In: WEISS, D. J.; WARDROP, K. J. Schalm's veterinary hematology. Ames: Blackwell Publishing, 2010. p. 821-828.

JOHNSON, L.; COOREV, C. P.; MARKS, D. C. The hemostatic activity of cryopreserved platelets is mediated by phosphatidylserine-expressing platelets and platelet microparticles. Transfusion, Arlington, v. 54, n. 8, p. 1917-1926, 2014.

KEVY, S.; JACOBSON, M. Preparation of growth factors enriched autologous platelet gel. In: ANNUAL MEETING OF THE SOCIETY FOR BIOMATERIALS, 27., 2001, Saint Paul. Proceedings... Saint Paul: Society for Biomaterials, 2001. p. 262.

LANDI, E. P.; ROVERI, E. G.; OZELO, M. C.; ANNICHINO-BIZZACCHI, J. M.; ORIGA, A. F.; CARVALHO REIS, A. R. de; SOUZA, C. A. de; MARQUES JÚNIOR, J. F. Effects of high platelet concentration in collecting and freezing dry platelets concentrates. Transfusion and Apheresis Science, Oxford, v. 30, n. 3, p. 205-212, 2004.

LEE, D. H.; BLAJCHMAN, M. A. Platelet substitutes and novel methods of platelet preservation. In: MICHELSON, A. D. Platelets. San Diego: Elsevier, 2007. p. 1297-1309.

MAIA, L.; SOUZA, M. V.; RIBEIRO JÚNIOR, J. I.; OLIVEIRA, A. C.; ALVES, G. E. S.; BENJAMIN, L. A.; SILVA, Y. F. R. S.; ZANDIM, B. M.; MOREIRA, J. C. L. Platelet-Rich plasma in the treatment of induced tendinopathy in horses: histologic evaluation. Journal of Equine Veterinary Science, Wildomar, v. 29, n. 8, p. 618626, 2009.

MARX, R. E. Platelet-Rich plasma: evidence to support its use. Journal of Oral and Maxillofacial Surgery, Philadelphia, v. 62, n. 4, p. 489-496, 2004.
MELARAGNO, A. J.; CARCIERO, R.; FEINGOLD, H.; TALARICO, L.; WEINTRAUB, L.; VALERI, C. R. Cryopreservation of human platelets using $6 \%$ dimethyl sulfoxide and storage at -80 degrees $\mathrm{C}$. Effects of 2 years of frozen storage at -80 degrees $\mathrm{C}$ and transportation in dry ice. Vox Sanguinis, Basel, v. 49, n. 4, p. 245-258, 1985.

METCALF, E. S. The effect of platelet-rich plasma (PRP) on intraluminal fluid and pregnancy rates in mares susceptible to persistent mating-induced endometritis (PMIE). Journal of Equine Veterinary Science, Wildomar, v. 34, n. 1, p. 128, 2014.

NEUHAUS, S. J.; WISHAW, K.; LELKENS, C. Australian experience with frozen blood products on military operations. The Medical Journal of Australia, Sydney, v. 192, n. 4, p. 203-205, 2010.

OHTO, H.; NOLLET, K. E. Overview on platelet preservation: better controls over storage lesion. Transfusion and Apheresis Science, Oxford, v. 44, n. 3, p. 321-325, 2011.

PEREIRA, R. C.F.; ZACARIAS, G. V.F.; CANTARELLI, C.; CORRÊA, M. M. B.; SILVA, G. B.; BARBOSA, A. L. T.; BRASS, K. E.; DE LA CÔRTE, F. D. Avaliação de sete protocolos para obtenção de plasma rico em plaquetas na espécie equina. Ciência Rural, Santa Maria, v. 43, n. 6, p. 1122-1127, 2013.

PICHEREAU, F.; DÉCORY, M.; RAMOS, G. C. Autologous platelet concentrate as a treatment for horses with refractory fetlock osteoarthritis. Journal of Equine Veterinary Science, Wildomar, v. 34, n. 4, p. 489-493, 2014.

REGHINI, M. F. S.; BUSSIERE, M. C. C.; RAMIRES NETO, C.; CASTRO-CHAVES, M. M. B.; RESENDE, H. L.; FIORATTI, E.; FARRAS, M. C.; ALVARENGA, M. A. Effect of use of platelet rich plasma on postbreading uterine inflammatory response of mares. Journal of Equine Veterinary Science, Wildomar, v. 34, n. 1, p. 127, 2014.

SCHOENFELD, H.; GRIFFIN, M.; MUHM, M.; DOEPFNER, U.R.; VON HEYMANN, C.; GÖKTAS, O.; EXADAKTYLOS, A.; RADTKE, H. Cryopreservation of platelets at the end of their conventional shelf life leads to severely impaired in vitro function. Cardiovascular Journal of South Africa, Durbanville, v. 17, n. 3, p. 125129, 2006. 
TABLIN, F.; WOLKERS, W. F.; WALKER, N. J.; OLIVER, A. E.; TSVETKOVA, N. M.; GOUSSET, K.;CROWE, L. M.; CROWE, J. H. Membrane reorganization during chilling: implications for longterm stabilization of platelets. Cryobiology, Rockville, v. 43, n. 2, p. 114-123, 2001.

VALERI, C. R.; FEINGOLD, H.; MARCHIONNI, L. D. A simple method for freezing human platelets using 6 per cent dimethylsulfoxide and storage at -80 degrees $\mathrm{C}$. Blood, New York, v. 43, n. 1, p. 131-136, 1974.

VENDRAMIN, F. S.; FRANCO, D.; NOGUEIRA, C. M.; PEREIRA, M. S.; FRANCO, T. R. Plateletrich plasma and growth factors: processing technique and application in plastic surgery. Revista do Colégio Brasileiro de Cirurgiões, Rio de Janeiro, v. 33, n. 1, p. 24-28, 2006.
WÜRZINGER, L. J.; SCHMID-SCHÖNBEIN, H. The role of fluid dynamics in triggering and amplifying haemostatic reactions in thrombogenesis. Monographs on Artherosclerosis, Basel, v. 15, p. 215-226, 1990.

ZANDIM, B. M.; SOUZA, M. V.; MAGALHÃES, P. C.; BENJAMIN, L. A.; MAIA, L.; OLIVEIRA, A. C.; PINTO, J. O.; RIBEIRO JÚNIOR, J. I. Platelet activation: ultrastructure and morphometry in plateletrich plasma of horses. Pesquisa Veterinária Brasileira, Rio de Janeiro, v. 32, n. 1, p. 83-92, 2012. 